\title{
Isolation and Molecular Characterization of Plant-Growth-Promoting Bacteria and Their Effect on Eggplant (Solanum melongena) Growth
}

\author{
Xuqing Li ${ }^{1}$, Jianli Yan ${ }^{1, *}$, Dingyi Li ${ }^{2}$, Yugen Jiang ${ }^{3}$, Ya Zhang ${ }^{1}$, Hong Wang ${ }^{1}$, Jingze Zhang ${ }^{4, * \mathbb{C}}$, \\ Temoor Ahmed ${ }^{4}$ and Bin $\mathrm{Li}^{4}$ \\ 1 Hangzhou Academy of Agricultural Science, Hangzhou 310024, China; lixqing@hz.cn (X.L.); \\ zhangyaae@gmail.com (Y.Z.); hnwanghong123@gmail.com (H.W.) \\ 2 Department of Biological Environment, Material and Environmental College, Shanxi Jinzhong Institute of \\ Technology, Jinzhong 030600, China; wangdc@hz.cn \\ 3 Agricultural Technology Extension Center of Fuyang District, Hangzhou 311400, China; fyjiangyg@gmail.com \\ 4 Institute of Biotechnology, Zhejiang University, Hangzhou 310058, China; temoorahmed@zju.edu.cn (T.A.); \\ libin0571@zju.edu.cn (B.L.) \\ * Correspondence: yanjianli00@gmail.com (J.Y.); jzzhang@zju.edu.cn (J.Z.)
}

\section{check for}

updates

Citation: Li, X.; Yan, J.; Li, D.; Jiang, Y.; Zhang, Y.; Wang, H.; Zhang, J.;

Ahmed, T.; Li, B. Isolation and

Molecular Characterization of

Plant-Growth-Promoting Bacteria and Their Effect on Eggplant (Solanum melongena) Growth Agriculture 2021, 11, 1258.

https://doi.org/10.3390/

agriculture11121258

Academic Editor: Mingcai Zhang

Received: 8 November 2021

Accepted: 10 December 2021

Published: 12 December 202

Publisher's Note: MDPI stays neutral with regard to jurisdictional claims in published maps and institutional affiliations.

Copyright: (c) 2021 by the authors. Licensee MDPI, Basel, Switzerland. This article is an open access article distributed under the terms and conditions of the Creative Commons Attribution (CC BY) license (https:// creativecommons.org/licenses/by/ $4.0 /)$
Abstract: In recent years, the optimum development of land resources has become an important task for ensuring the security of food production in China. Soil microorganisms have been considered to play an important role in conferring soil fertility and productivity. In order to obtain the plant-growthpromoting bacteria in newly reclaimed land, a total of 988 bacterial strains were isolated from nine soil samples collected from different sites in wastelands in Hangzhou (Zhejiang Province, China), a rural mountainous area. Among them, five strains exhibited substantial potential of phosphate solubilization, nitrogen fixation, siderophore production and indole acetic acid production at both pH 5.0 and pH 7.0, and also promoted eggplant growth in immature soil from newly reclaimed land. Furthermore, bacterial strains ZJ62 and ZJ3-12 were identified as Pantoea dispersa and Pantoea ananatis, respectively, while strains ZJ5, ZJ9 and ZJ174 were identified as Burkholderia arboris, Burkholderia pyrrocinia and Burkholderia pyrrocinia, respectively, based on colony morphology observation and phylogenetic analysis of $16 \mathrm{~S}$ rDNA and the housekeeping genes sequences. Overall, the result of this study showed that the 5 obtained bacterial strains have a great potential in promoting plant growth in immature soil from newly reclaimed land.

Keywords: newly reclaimed land; $16 \mathrm{~S}$ rRNA sequencing; housekeeping genes sequencing; PGPB; Pantoea; Burkholderia

\section{Introduction}

The limitation of available land resources and the gradual decrease of arable area with the expansion of urbanization have led to food supply challenges in China [1]. To meet the demand for land, we carried out a land reclamation of the benchland in the mountainous outskirts of the city of Hangzhou (Zhejiang Province, China), by raising the elevation of a waterbed and low-lying land using immature soils produced from road or reservoir construction. However, the immature soils are those, which are new and not fully developed, characterized by slight weathering of the mineral material and generally containing a small amount of organic matter. These soils are not suitable for plant growth due to high gravel content, acidity and low nutrient contents [2].

Organic amendments, such as livestock manure, biosolids, wood residuals, and crop residues, have been widely used in soil reclamation owing to their ability to modify soils' physical and chemical properties [3,4]. Meanwhile, the use of organic residues as amendments greatly influences soil microbial communities, which improves soil organic matter level and long-term soil fertility and improves soil health and productivity [5]. In 
addition, soil bacteria that thrive in the rhizosphere, colonize plant roots and facilitate plant growth are designated as plant growth-promoting bacteria (PGPB) [6].

Due to land shortage, mountain vegetable cultivation has developed rapidly in recent years in Zhejiang Province, China, especially in Hangzhou [2,7]. Among these mountain vegetables, eggplant is the most popular due to its various advantages, such as rich nutritional properties and good taste [7]. In order to promote mountain eggplant production, soil reclamation was carried out by widely applying organic amendments, such as biosolids, livestock manure, wood residuals, pulp byproducts and crop residues. Organic amendments have greatly improved the physical and chemical properties of mountain soil and significantly enriched heterotrophic microbial communities $[2,8]$.

In agricultural soils, plant growth-promoting microorganisms as green bio-inoculants can enhance plant growth and abiotic stresses as well as protect plants from disease through different mechanisms $[9,10]$. The application of PGPB-based biofertilizers in the soil is considered as eco-friendly, inexpensive, and sustainable alternative to hazardous chemical fertilizers [11]. Several studies reported that PGPB influences plant growth by biological nitrogen fixation, phosphate solubilization, siderophores production, and regulation of hormones and hormone like molecules like auxins, cytokinins, gibberellins, abscisic acid and ethylene [12-14]. However, to the best of our current knowledge, there is very little information available on effect of PGPB on plant growth in immature soil [15-17].

We hypothesize that the PGPB from immature soil can survive well in new reclamation land. This study aims to isolate and characterize the native bacterial isolates, which have a great ability in phosphate solubilization, nitrogen fixation, siderophore and indole acetic acid production, and plant growth promotion in immature soil from newly reclaimed land. Furthermore, the selected bacterial strains were identified based on colony morphology observation and phylogenetic analysis of $16 \mathrm{~S}$ rDNA and the housekeeping gene sequences.

\section{Materials and Methods}

\subsection{Sample Collection}

In order to isolate PGPB, nine soil samples were collected from different wastelands sites, which were abandoned for many years at a mountainous rural area of Yuqian town in the city of Hangzhou $\left(119^{\circ} 25^{\prime} 26^{\prime \prime}\right.$ E, $30^{\circ} 7^{\prime} 29^{\prime \prime} \mathrm{N}$, Zhejiang Province, China) in November 2019. The soils had a $\mathrm{pH}$ of 5.24 , with $6.78 \mathrm{~g} / \mathrm{kg}$ of organic matter, $0.046 \%$ of total $\mathrm{N}$, $1.6 \mathrm{mg} / \mathrm{kg}$ of available $\mathrm{P}$, and $57 \mathrm{mg} / \mathrm{kg}$ of available $\mathrm{K}$, while the soil type is acrisols (acidic soils with a layer of clay accumulation), according to the soil classification system of FAO-UNESCO. The soils were sampled from a $5-20 \mathrm{~cm}$ soil layer, and samples were transported to the laboratory in sterilized polythene bags.

\subsection{Bacterial Isolation}

A soil suspension was prepared by adding $1 \mathrm{~g}$ of soil into $99 \mathrm{~mL}$ of sterile water followed by 10 -fold serial dilution. Bacteria were isolated by inoculating $200 \mu \mathrm{L}$ of each dilution on a nutrient agar (NA) medium (beef extract $5 \mathrm{~g}$, peptone $5 \mathrm{~g}, \mathrm{NaCl} 5 \mathrm{~g}$, agar $20 \mathrm{~g}$, distilled water $1000 \mathrm{~mL}, \mathrm{pH}=7.0$ ) and then incubating the plates at $28^{\circ} \mathrm{C}$ for $24 \mathrm{~h}$. After purification by repeated streaking on NA medium at least three times, different colonies were selected based on their morphological characteristics such as shape, color, size, regular or irregular and convex or flat. The purified bacterial strains were stored at $-70{ }^{\circ} \mathrm{C}$ in $30 \%$ glycerol solution. In order to test bacterial abilities associated with the plant growth promotion, a single bacterial colony was picked up from the NA medium and then incubated in nutrient broth at $30^{\circ} \mathrm{C}, 180 \mathrm{rpm}$ for $24 \mathrm{~h}$. After centrifugation at $10,000 \times g$, $4{ }^{\circ} \mathrm{C}$ for $5 \mathrm{~min}$ and washing three times with sterile water, the initial bacterial density was prepared by adjusting cells suspension to an optical density at $600 \mathrm{~nm}\left(\mathrm{OD}_{600}\right)$ of 0.85 (approximately $1 \times 10^{8} \mathrm{cfu} / \mathrm{mL}$ ). The correlation between the $\mathrm{OD}_{600}$ value and bacterial density was determined by measuring the $\mathrm{OD}_{600}$, plating the appropriate bacterial dilution onto NA medium and incubating overnight at $30^{\circ} \mathrm{C}$. 


\subsection{Evaluation of Phosphate Solubilization Activity}

The phosphate $(\mathrm{P})$ solubilization activity was evaluated according to the method of [18] with minor modification by inoculating bacterial colonies on a modified National Botanical Research Institute's phosphate growth medium (NBRIP, glucose $10 \mathrm{~g}, \mathrm{MgCl}_{2}$ $5 \mathrm{~g}, \mathrm{KCl} 0.2 \mathrm{~g}$, $\mathrm{MgSO}_{4} \cdot 7 \mathrm{H}_{2} \mathrm{O} 0.25 \mathrm{~g}$, $\left(\mathrm{NH}_{4}\right)_{2} \mathrm{SO}_{4} 0.1 \mathrm{~g}, \mathrm{Ca}_{3}\left(\mathrm{PO}_{4}\right)_{2} 5 \mathrm{~g}$, agar $18 \mathrm{~g}$, distilled water $1000 \mathrm{~mL}, \mathrm{pH}=5.0$ or 7.0). The solubilize phosphate ability of each strain under acid conditions was determined by adjusting the $\mathrm{pH}$ of media to 5.0 before autoclaving. After incubating bacteria on the NBRI-MTSB media at $30^{\circ} \mathrm{C}$ for $3 \mathrm{~d}$, the P-solubilizing ability of all bacteria were assessed by observing the formation of a halo around the colony and measuring the P-Solubility Index (PSI), which was calculated as described by [19]. Each assay was performed in triplicate.

\subsection{Measurement of Siderophore Production}

Bacterial strains with high P-solubilizing activity were further evaluated for their ability to produce siderophores, which was determined as described by [20] using the CAS universal chemical assay. All glassware was soaked overnight in $6 \mathrm{M} \mathrm{HCl}$ and rinsed with distilled Millipore water several times to remove traces of iron. After culture in LB in a WY-211B rotary shaker (Shanghai Zhicheng Instrument Co., Ltd, Shanghai, China) at $180 \mathrm{rpm}$ at $30{ }^{\circ} \mathrm{C}$ for $20 \mathrm{~h}$, bacteria were harvested by centrifugation at $3000 \times g$ for 5 min and then resuspended in iron-deficient minimum salt medium 9 (MM9) [20]. After incubating the bacteria on MM9 for $24 \mathrm{~h}$ and adjusting the density of cell suspension to $10^{7} \mathrm{cfu} / \mathrm{mL}$, a sterile filter paper disc $(5 \mathrm{~mm})$ inoculated with $10 \mu \mathrm{L}$ bacterial suspension was placed into the center of a Chrome Azurol S (CAS) solid medium. The siderophore production by the strains was determined by observing the production of orange halo.

\subsection{Determination of Nitrogen-Fixing Ability}

Bacterial strains with high P-solubilizing activity were further evaluated for their nitrogen-fixing ability, according to previously described method [21]. In brief, bacteria were grown in nutrient broth (NB) (1\% tryptone, $0.1 \%$ yeast extract, $1 \%$ sucrose, $0.3 \%$ peptone) for $20 \mathrm{~h}$, and harvested by centrifugation at $3000 \times g$ for $5 \mathrm{~min}$ and then resuspended in the $\mathrm{N}$-free malate $(\mathrm{Nfb})$ broth $\left(\mathrm{KH}_{2} \mathrm{PO}_{4} 0.4 \mathrm{~g}, \mathrm{~K}_{2} \mathrm{HPO}_{4} 0.1 \mathrm{~g}, \mathrm{MgSO}_{4} \cdot 7 \mathrm{H}_{2} \mathrm{O}\right.$ $0.2 \mathrm{~g}, \mathrm{NaCl} 0.1 \mathrm{~g}, \mathrm{CaCl}_{2} 0.02 \mathrm{~g}, \mathrm{FeCl}_{3} 0.01 \mathrm{~g}, \mathrm{MoO}_{4} \mathrm{Na} \cdot 2 \mathrm{H}_{2} \mathrm{O} 0.002 \mathrm{~g}$, sodium malate $5.0 \mathrm{~g}$,

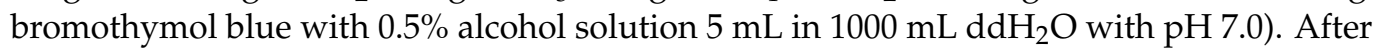
adjusting the density of cell suspension to $10^{7} \mathrm{cfu} / \mathrm{mL}, 10 \mu \mathrm{L}$ cell resuspension was added to the test tube containing $5 \mathrm{~mL}$ of the $\mathrm{Nfb}$ broth and then the test tubes were incubated at $30^{\circ} \mathrm{C}$ in a rotary shaker at $180 \mathrm{rpm}$ for $2 \mathrm{~d}$. The nitrogen-fixing ability was determined by observing the color change in the test tubes.

\subsection{Detection of Indole Acetic Acid (IAA)}

Bacterial strains with high P-solubilizing activity were further evaluated for their IAA production ability. In brief, after incubating bacteria in NB in a WY-211B rotary shaker at $180 \mathrm{rpm}$ at $30^{\circ} \mathrm{C}$ for $20 \mathrm{~h}$ and then the density of cell suspension was adjusted to $10^{7} \mathrm{cfu} / \mathrm{mL}, 10 \mu \mathrm{L}$ cell resuspension was added to test tube containing $5 \mathrm{~mL} \mathrm{NB}$ with $0.1 \%$ tryptophan. The test tubes were incubated as above condition for $48 \mathrm{~h}$ and then centrifuged at $8000 \mathrm{rpm}$ for $5 \mathrm{~min}$. One $\mathrm{mL}$ of supernatant from each test tube was mixed with $4 \mathrm{~mL}$ Salkowski's reagent $\left(0.5 \mathrm{~mol} / \mathrm{L} \mathrm{FeCl}_{3} 15 \mathrm{~mL}, \mathrm{H}_{2} \mathrm{SO}_{4} 300 \mathrm{~mL}\right.$, ddH $\left.\mathrm{dd}_{2} \mathrm{O} 500 \mathrm{~mL}\right)$ [22], and the test tubes were incubated at room temperature for $30 \mathrm{~min}$ in the dark. The IAA production was determined by observing the development of a pink-red color and measuring the optical density at a wavelength of $530 \mathrm{~nm}$ with a UV-VIS spectrophotometer (Perkin Elmer Lambda 35, Waltham, MA, USA). Furthermore, the IAA concentration value was calculated using a standard curve by standard IAA $(0-100 \mu \mathrm{g} / \mathrm{mL})$, while the amount of the produced IAA was expressed as $\mu \mathrm{g}$ IAA secreted per unit of optical density. 


\subsection{Effect of Five Strains on Plant Growth Promotion in New Reclamation Land}

The effect of PGPB strains on plant growth promotion was evaluated in soil from new reclamation land. In brief, seeds of the eggplant cv. Hangqie2010 (an eggplant F1 hybrid bred developed by the Vegetable Institution, Hangzhou Academy of Agricultural Sciences) was sterilized with $2 \%$ sodium hypochlorite solution for $2 \mathrm{~min}$ and rinsed three times with sterile water and soaked in sterile water for $5 \mathrm{~h}$ and then air-dried in a laminar flow hood. After incubation on the sterilized filter papers at $25^{\circ} \mathrm{C}$ for $3 \mathrm{~d}$, the germinated seeds were sowed into the 32-cell seed growing trays containing the cocopeat substrate (Bairun Agricultural Technology Co., Ltd., Hangzhou, China), which was put in the greenhouse with a relative humidity level of $70-80 \%$ and temperatures of $30^{\circ} \mathrm{C}$. The cells suspension of the selected strains was prepared by overnight culture in LB broth on a rotary shaker for $180 \mathrm{rpm}$ at $30^{\circ} \mathrm{C}$ for $20 \mathrm{~h}$ and adjusting the density to about $10^{8} \mathrm{cfu} / \mathrm{mL}$.

At the four-leaf stage (about six weeks after sowing), they were transplanted into pots containing unsterilized soil from the new reclamation land with $\mathrm{pH} 5.0$, and $10 \mathrm{~mL}$ of cell suspension of each test strain was poured into the soil around the plants and then incubated under the same condition above. The plants inoculated with sterile water were used as the control. Ten plants $(n=10)$ were used for each treatment and three independent replicates were performed for each treatment. The seedlings were observed daily and their changes were recorded. After $30 \mathrm{~d}$ of inoculation, seedlings height, root length, fresh and dry weight were determined by removing eggplant seedlings from each pot and rinsing them with tap water. Dry weight measurement was performed by drying the plants in an oven at $65{ }^{\circ} \mathrm{C}$ for $2 \mathrm{~d}$. The growth promotion efficacy (GPE)\% was calculated using the following formula: GPE $\%=($ treatment - control $) /$ control $\times 100 \%$.

\subsection{Identification of Bacterial Strains}

The selected strains were further identified based on sequence analysis of 16S rDNA as described by [23] In brief, bacteria were cultured on LB broth at $30^{\circ} \mathrm{C}$ for $24 \mathrm{~h}, 16 \mathrm{~S}$ rRNA genes of the strains were amplified with primer pairs $27 \mathrm{~F}$ and $1492 \mathrm{R}$ in an automated thermal cycler (Eppendorf AG, Hamburg, Germany) [24]. The amplified products were sent to the Sangon Biotech Company Limited (Shanghai, China) using the Sanger method to sequence both strands on an automated DNA sequencer. The resulting sequence was edited, compared with others in the GenBank database, using BLAST to search for the most similar sequences and the strains were assigned to different genera. Furthermore, the identity of Pantoea spp. was determined by amplification of the $\operatorname{at} \mathrm{D}, g y r \mathrm{~B}$, inf $\mathrm{B}$ and rpoB genes using primer pairs atpD 01-F/02-R, gyrB 01-F/02-R, infB 01-F/02-R and rpoB CM7-F/CM31b-R, respectively, while the identity of Burkholderia spp. was determined by amplification of $a t p D, g y r B, g l t \mathrm{~B}, l e p \mathrm{~A}, p h a \mathrm{C}, \operatorname{rec} \mathrm{A}$ and $\operatorname{tr} p \mathrm{~B}$ genes using the corresponding primer pairs (https:/ / pubmlst.org/organisms/burkholderia-cepacia-complex/primers; accessed on 26 August 2021). The amplification was carried out in a $50 \mu \mathrm{L}$ reaction volume containing $32.5 \mu \mathrm{L} \mathrm{ddH}_{2} \mathrm{O}, 5 \mu \mathrm{L} 10 \times$ PCR buffer, $4 \mu \mathrm{L} 2.5 \mathrm{mM}$ dNTP, $2 \mu \mathrm{L} 10 \mu \mathrm{M}$ of each primer, $4 \mu \mathrm{L}$ template and DNA $0.5 \mu \mathrm{L} 5 \mathrm{U} / \mu \mathrm{L}$ Taq DNA polymerase (TaKaRa Bio Inc., Shiga, Japan). The purified PCR products were submitted to the Sangon Biotech Company Limited (Shanghai, China) for sequencing in both directions.

The obtained sequences were assembled using DNASTAR Lasergene version 7.1.0 and edited using BioEdit version 1.83 [25], and analyzed by BLAST search in GenBank database. The reference sequences of closely related species for Pantoea spp. were downloaded from GenBank database (Supplementary Materials Table S1). For Burkholderia app. (Supplementary Materials Table S2), the reference sequences of each species were downloaded from the Burkholderia cepacia complex (Bcc) multilocus sequence typing (MLST) website (http:/ / pubmlst.org/bcc/; accessed on 26 August 2021). Phylogenic trees were constructed with RaxmlGUI v. 1.5 using the maximum likelihood (ML) method [26]. 


\subsection{Statistical Analysis}

Statistical analysis was done using SPSS software version 16 (SPSS Inc., Chicago, IL, USA). The levels of significance $(p<0.05)$ of the main treatments and their interactions were calculated through an analysis of variance after testing for normality and variance homogeneity.

\section{Results and Discussion}

\subsection{P-Solubilizing Ability of Bacterial Strains}

A total of 988 bacterial strains were isolated from nine soil samples, which were collected from different sites in wastelands abandoned for many years in Hangzhou, (Zhejiang Province, China), a mountainous rural area. The P-solubilization assays showed that only five bacterial strains produced the clear P-solubilizing zones $(>1.0 \mathrm{~cm})$ at either $\mathrm{pH} 7.0$ or $\mathrm{pH}$ 5.0, while no clear zones were found in other bacterial strains (Table 1). Indeed, the PSI\% of the five strains ZJ62, ZJ3-12, ZJ9, ZJ174 and ZJ5 was $141.7 \%, 87.5 \%, 95.83 \%$, $108.3 \%$ and $95.83 \%$ at $\mathrm{pH} 7.0$, while the PSI\% of the five strains ZJ62, ZJ3-12, ZJ9, ZJ174 and ZJ5 was $133.3 \%, 93.1 \%, 118.8 \%, 110.4 \%$ and $100.0 \%$ at pH 5.0, respectively (Figure 1 ).

Table 1. The ability of the five selected bacterial strains in P-solubilization, siderophores production and $\mathrm{N}$-fixation.

\begin{tabular}{ccccccc}
\hline \multirow{2}{*}{ Strains } & \multicolumn{2}{c}{ P-Solubilization Ability (cm) } & \multicolumn{2}{c}{ Siderophore Production (cm) } & \multicolumn{2}{c}{ N-Fixation } \\
\cline { 2 - 7 } & pH 5.0 & pH 7.0 & pH 5.0 & pH 7.0 & pH 5.0 & pH 7.0 \\
\hline ZJ3-12 & $1.16 \pm 0.05 \mathrm{~d}$ & $1.12 \pm 0.08 \mathrm{c}$ & $1.11 \pm 0.21 \mathrm{~cd}$ & $0.94 \pm 0.06 \mathrm{c}$ & + & + \\
ZJ5 & $1.20 \pm 0.05 \mathrm{~cd}$ & $1.17 \pm 0.06 \mathrm{c}$ & $1.24 \pm 0.19 \mathrm{~b}$ & $0.99 \pm 0.05 \mathrm{c}$ & + & + \\
ZJ9 & $1.31 \pm 0.13 \mathrm{ab}$ & $1.18 \pm 0.10 \mathrm{c}$ & $1.06 \pm 0.11 \mathrm{~d}$ & $0.85 \pm 0.03 \mathrm{~d}$ & + & + \\
ZJ62 & $1.40 \pm 0.06 \mathrm{a}$ & $1.45 \pm 0.04 \mathrm{a}$ & $1.21 \pm 0.15 \mathrm{bc}$ & $1.20 \pm 0.09 \mathrm{a}$ & + & + \\
ZJ174 & $1.26 \pm 0.13 \mathrm{bc}$ & $1.25 \pm 0.04 \mathrm{~b}$ & $2.12 \pm 0.12 \mathrm{a}$ & $1.10 \pm 0.08 \mathrm{~b}$ & + & + \\
\hline
\end{tabular}

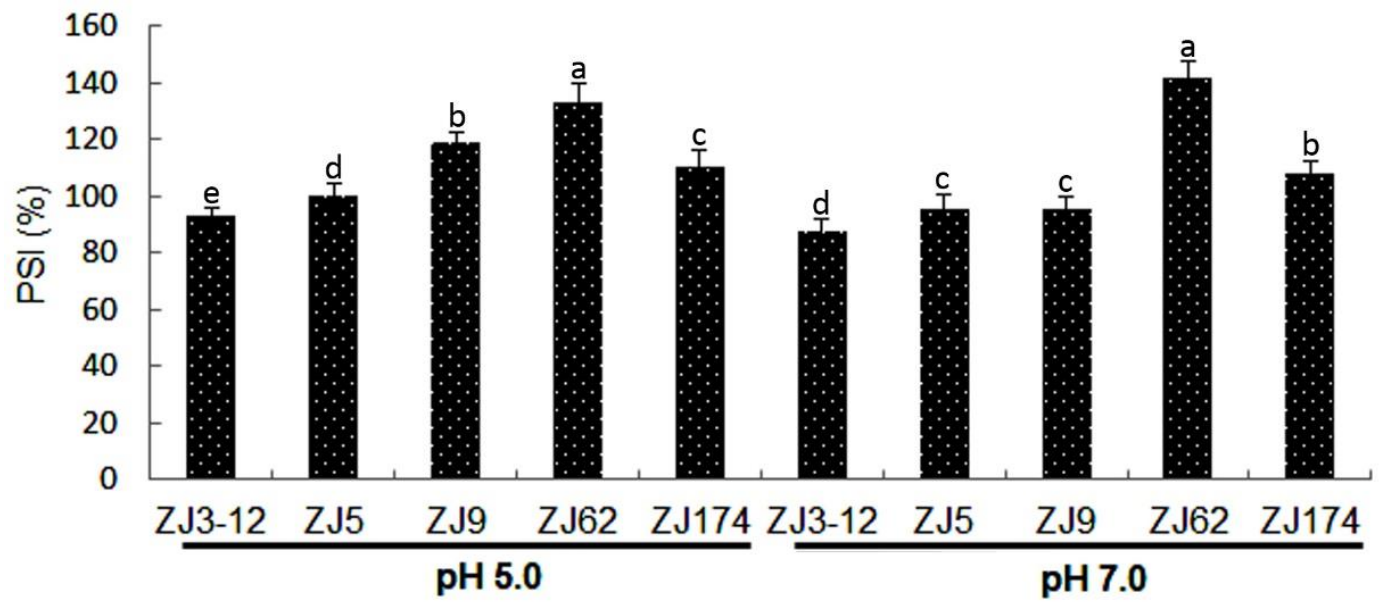

Figure 1. Phosphate solubilization index (PSI)\% of five bacterial strains (ZJ3-12, ZJ5, ZJ9, ZJ62 and ZJ174) was determined by inoculating bacteria on National Botanical Research Institute Phosphate (NBRIP) media at pH 5.0 or pH 7.0 and measuring the diameter of halo zone after $3 \mathrm{~d}$ of incubation. PSI $=$ (diameter of colony + halo zone $(\mathrm{cm})-$ diameter of colony $(\mathrm{cm})) /$ diameter of colony $(\mathrm{cm}) \times 100$ [19]. Vertical bars represent the standard deviation of the means $(\mathrm{n}=3)$. Bars followed by the different letters are significantly different at $p<0.05$ according to LSD.

As we know, $\mathrm{P}$ is one of the essential macronutrients, along with nitrogen, required by the plants for their survival and vital functions, while phosphatic fertilizer is often added to fulfill the phosphate requirement of plants $[27,28]$. However, acidic soils rapidly retain applied phosphorus fertilizers and consequently present low nutrient availability to plants. Indeed, in acidic soil, the fixation of phosphate by aluminium and iron is very pronounced, limiting the availability of soluble phosphate for plant uptake $[29,30]$. 
Therefore, more and more studies paid attention to phosphate solubilizing microorganisms in particular bacteria.

Results from this study indicated that five bacterial strains exhibited strong phosphate solubilization ability in both $\mathrm{pH} 7.0$ and $\mathrm{pH} 5.0$ although they differed in P-solubilizing ability. Among the five strains, ZJ62 exhibited the highest PSI\% at $\mathrm{pH} 7.0$ and $\mathrm{pH} 5.0$, whereas ZJ3-12 showed the lowest PSI\% at $\mathrm{pH} 7.0$ and $\mathrm{pH}$ 5.0. Due to the fact most immature soil from newly reclaimed land is usually very acidic, this result showed that the five strains have great potential in improving soil quality and promoting plant growth. In agreement with the result of this study, previous reports also indicated that the inoculation of phosphate solubilizing bacteria in soils can restore the overall balance of nutrients and health of the soil to sustain it for plant growth and agricultural production [30,31]. This may be due to the secretion of organic acids and phosphatases, which convert insoluble phosphates into soluble phosphate that plants can utilize.

\subsection{Siderophore Production}

Results from this study indicated that the five selected bacterial strains all produced orange halos around colonies after $3 \mathrm{~d}$ of incubation on MM9 medium with CAS at both pH 5.0 and pH 7.0 (data not shown). However, the halo diameter varied within the five bacterial strains. Indeed, the halo diameters of strains ZJ62, ZJ174, ZJ5, ZJ3-12, and ZJ9 were $1.20,1.10,0.99,0.94$ and $0.85 \mathrm{~cm}$, respectively, at $\mathrm{pH} 7.0$, while the halo diameters of strains ZJ62, ZJ174, ZJ5, ZJ3-12, and ZJ9 were 1.21, 2.12, 1.24, 1.11 and $1.06 \mathrm{~cm}$ at $\mathrm{pH} 5.0$. Furthermore, the result of this study also indicated that the halo diameter of strains also depends on the $\mathrm{pH}$. Indeed, strain $\mathrm{ZJ} 174$ exhibits the greatest siderophore production at $\mathrm{pH}$ 5.0, while strain ZJ62 exhibits the significant siderophore production at $\mathrm{pH} 7.0$ (Figure 2, Table 1).
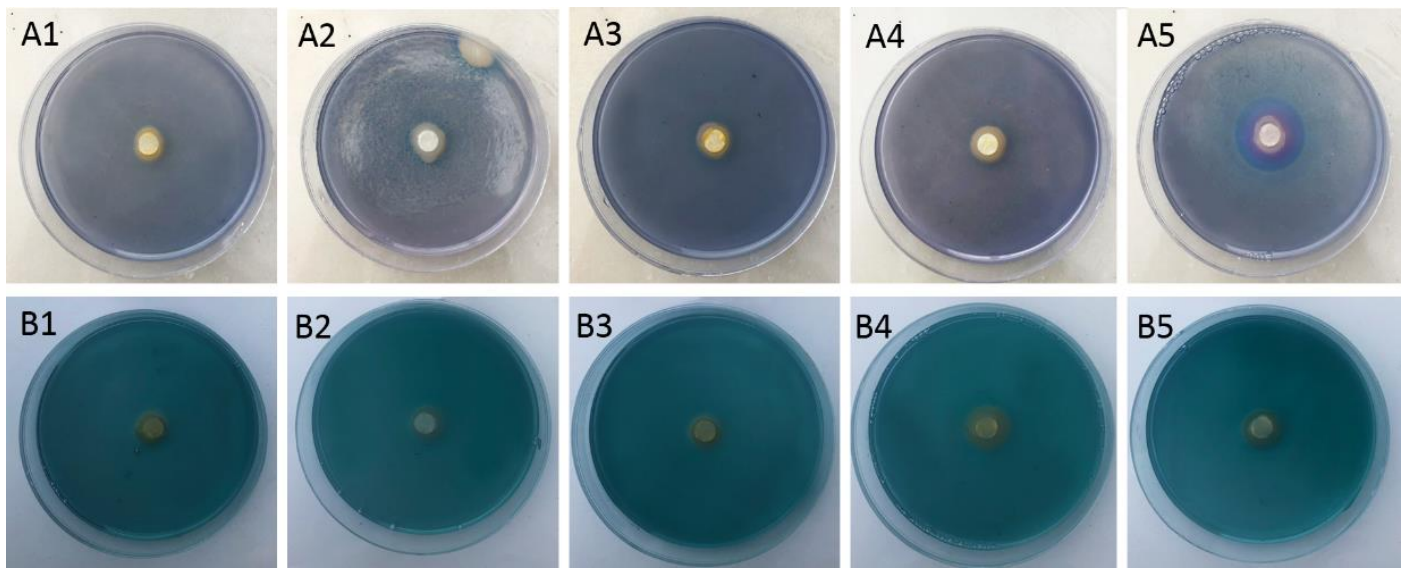

Figure 2. Siderophores production of five strains was determined by inoculating $10 \mu \mathrm{L}$ bacterial suspension on a sterile filter paper disc $(5 \mathrm{~mm})$ that placed into the center of a chrome azurol sulphonate solid medium at different $\mathrm{pH}$ and observing the production of orange halo after $3 \mathrm{~d}$ of incubation. Bacterial suspension was prepared by incubating cells in iron-deficient minimum salt medium 9 for $24 \mathrm{~h}$ and then adjusting the density of cell suspension to $10^{7} \mathrm{cfu} / \mathrm{mL}$. (A). $\mathrm{pH}$ 5.0. (B). pH 7.0. 1-5: Strains ZJ3-12, ZJ5, ZJ9, ZJ62 and ZJ174.

Siderophores have been reported to play an important role in the survival, colonization, and growth of PGPB in poor nutrient conditions by improving Fe utilization [32,33]. Indeed, the actual bioavailability of $\mathrm{Fe}$ is limited by its tendency to form insoluble ferric $\left[\mathrm{Fe}^{3+}\right]$ complexes. Thus, most Fe is tied up in soil at these biologically relevant $\mathrm{pH}$ values, rendering it mainly unavailable to soil microbes (such as bacteria, fungi, oomycetes) and plants. In agreement with the result of this study, our recent studies indicated that soil microbes could secrete into the rhizosphere environment a variety of siderophores that perform a Fe scavenging role. Siderophores interact with the ferric $\mathrm{Fe}$; the $\mathrm{Fe}$ is then transported into the cell, reduced to the biologically relevant ferrous $\left(\mathrm{Fe}^{2+}\right)$ form $[34,35]$. 


\subsection{Nitrogen Fixation Ability}

It is well known that the N-fixation ability has a crucial role in bacterial survival, growth, and beneficial effect on plants. Thus, the $\mathrm{N}$-fixation ability of five bacterial strains was evaluated by inoculating and incubating bacteria on the $\mathrm{Nfb}$ media with different $\mathrm{pH}$ values. The results of this study indicated that the color of the NfB media had changed from green to blue at $\mathrm{pH} 7.0$ or from yellow to blue at $\mathrm{pH} 5.0$ after $2 \mathrm{~d}$ of incubation, indicating that the five strains can fix atmospheric nitrogen (Figure 3, Table 1). In agreement with the result of this study, our previous studies have isolated and characterized a lot of soil bacteria with the $\mathrm{N}$-fixation ability from farming soil samples in China [36].
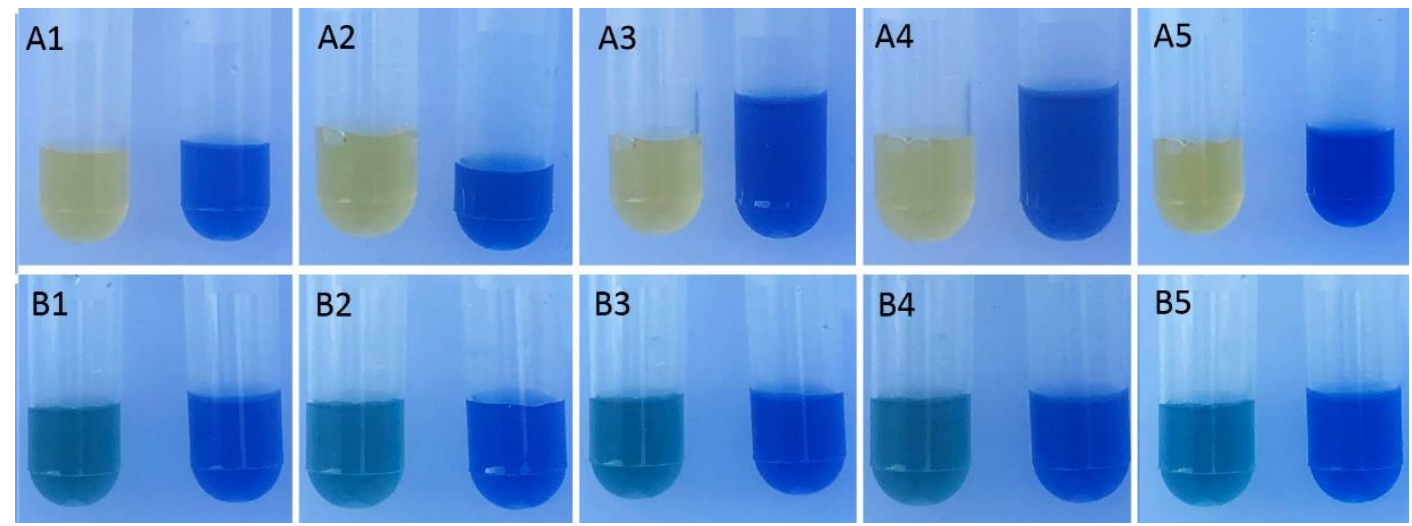

Figure 3. N-fixation ability of five strains was determined by inoculating $10 \mu \mathrm{L}$ bacterial resuspension to the test tube containing $5 \mathrm{~mL}$ of the $\mathrm{N}$-free malate broth with different $\mathrm{pH}$, and then observing the color change in the test tubes after incubation at $30{ }^{\circ} \mathrm{C}$ in a rotary shaker at $180 \mathrm{rpm}$ for $2 \mathrm{~d}$. Bacterial resuspensions were prepared by resuspending bacteria grown in nutrient broth in the $\mathrm{N}$-free malate broth and then adjusting the cell density to $10^{7} \mathrm{cfu} / \mathrm{mL}$. (A). pH 5.0. (B). pH 7.0. 1-5: Strains ZJ3-12, ZJ5, ZJ9, ZJ62 and ZJ174. In each treatment, Control is on the left, strain is on the right.

\subsection{Indole Acetic Acid (IAA) Detection}

The IAA production ability of the five selected bacterial strains was evaluated by the change of color according to the spectrophotometric analysis following the incubation of bacteria in NB broth supplemented with $0.1 \%$ tryptophan. The results of this study indicated that the amount of IAA production of strains ZJ5, ZJ9, ZJ3-12, ZJ62 and ZJ174 was $123.92,70.17,67.33,23.25$ and $18.58 \mu \mathrm{g} / \mathrm{mL}$, respectively, at pH 7.0, while the amount of IAA production of strains ZJ5, ZJ9, ZJ3-12, ZJ62 and ZJ174 was 11.83, 20.75, 29.58, 9.92 and $17.67 \mu \mathrm{g} / \mathrm{mL}$, respectively, at pH 5.0 (Figures 4 and 5, Table 2).

Table 2. Production of IAA by five strains on nutrient broth of different $\mathrm{pH}$ with $0.1 \%$ tryptophan.

\begin{tabular}{cccc}
\hline Strains $(\mathbf{p H} \mathbf{5 . 0})$ & IAA $(\mu \mathbf{g} / \mathbf{m L})$ & Strains $(\mathbf{p H} \mathbf{7 . 0})$ & IAA $(\mu \mathbf{g} / \mathbf{m L})$ \\
\hline ZJ3-12 & $29.58 \pm 1.38 \mathrm{a}$ & ZJ3-12 & $67.33 \pm 2.60 \mathrm{~b}$ \\
ZJ5 & $11.83 \pm 0.63 \mathrm{~d}$ & ZJ5 & $123.92 \pm 1.70 \mathrm{a}$ \\
ZJ9 & $20.75 \pm 1.09 \mathrm{~b}$ & ZJ9 & $70.17 \pm 0.52 \mathrm{~b}$ \\
ZJ62 & $9.92 \pm 0.80 \mathrm{e}$ & ZJ62 & $23.25 \pm 1.09 \mathrm{c}$ \\
ZJ174 & $17.67 \pm 0.63 \mathrm{c}$ & ZJ174 & $18.58 \pm 0.38 \mathrm{~d}$ \\
\hline
\end{tabular}

The IAA concentration value was expressed as $\mu \mathrm{g}$ IAA, which was calculated as described in Figure 5 . Values followed by different lowercase letters within the same column indicate a significant difference at $p<0.05$.

Previous studies have indicated that IAA has an important role in plant growth promotion of beneficial bacteria $[37,38]$. Interestingly, the results of this study showed that all tested strains were able to produce IAA, suggesting they may have a great potential in plant growth promotion. Furthermore, this study also found that the production ability differed among different strains. In addition, the IAA production ability of the five selected strains depended on the $\mathrm{pH}$ of broth. Indeed, the IAA production ability of all strains except strain 
ZJ174 was higher at $\mathrm{pH} 7.0$ than that of $\mathrm{pH}$ 5.0, while there was no significant difference between $\mathrm{pH} 5.0$ and $\mathrm{pH} 7.0$ in the IAA production ability of strain ZJ174 (Figures 4 and 5, Table 2).

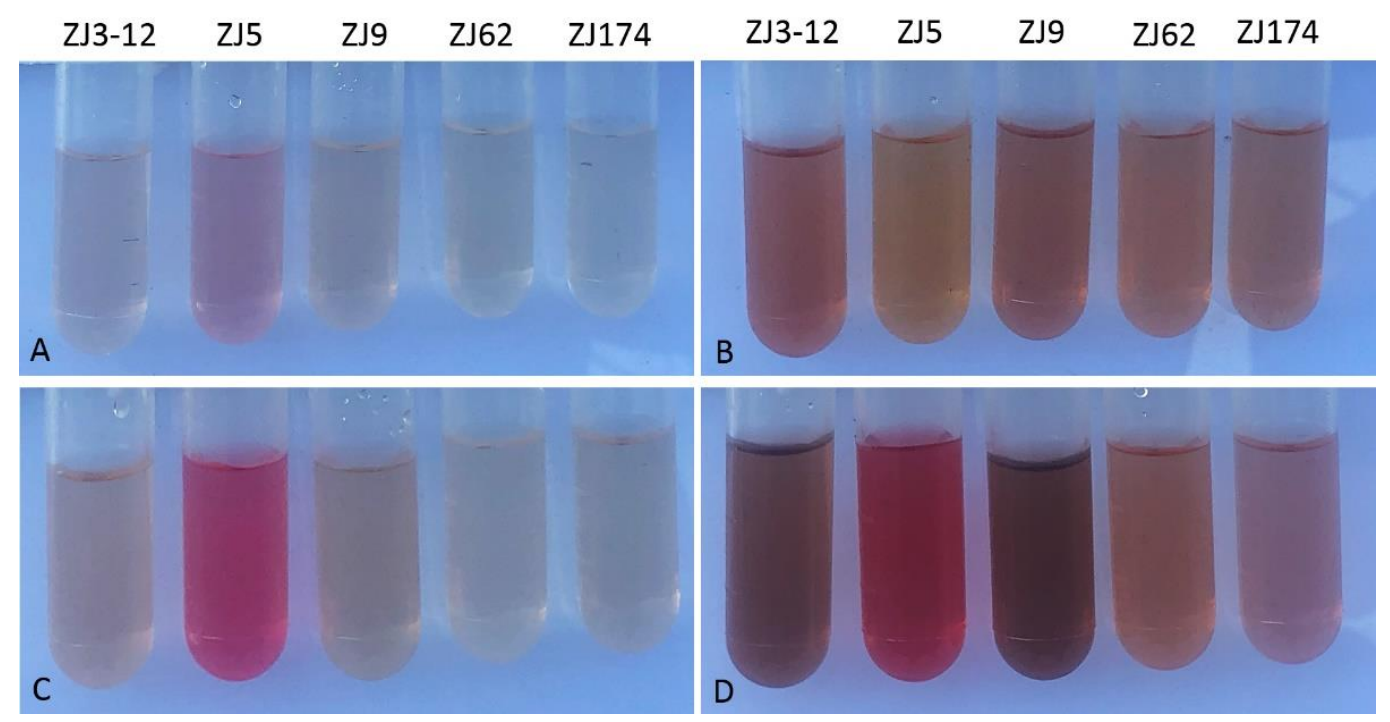

Figure 4. The IAA production of five strains at different $\mathrm{pH}$ was determined by observing the development of a pink-red color after adding $10 \mu \mathrm{L}$ bacterial resuspension to test tube containing $5 \mathrm{~mL}$ nutrient broth with $0.1 \%$ tryptophan, mixing $1 \mathrm{~mL}$ of supernatant from each test tube with $4 \mathrm{~mL}$ Salkowski's reagent, and incubating the test tubes at room temperature for $30 \mathrm{~min}$ in the dark. Bacterial suspension was prepared by incubating bacteria in nutrient broth at $180 \mathrm{rpm}$ at $30{ }^{\circ} \mathrm{C}$ for $20 \mathrm{~h}$ and then adjusting the density of cells to $10^{7} \mathrm{cfu} / \mathrm{mL}$. (A). without tryptophan at $\mathrm{pH}$ 5.0. (B). $0.1 \%$ tryptophan at $\mathrm{pH}$ 5.0. (C). without tryptophan at $\mathrm{pH}$ 7.0. (D). 0.1\% tryptophan at $\mathrm{pH}$ 7.0.

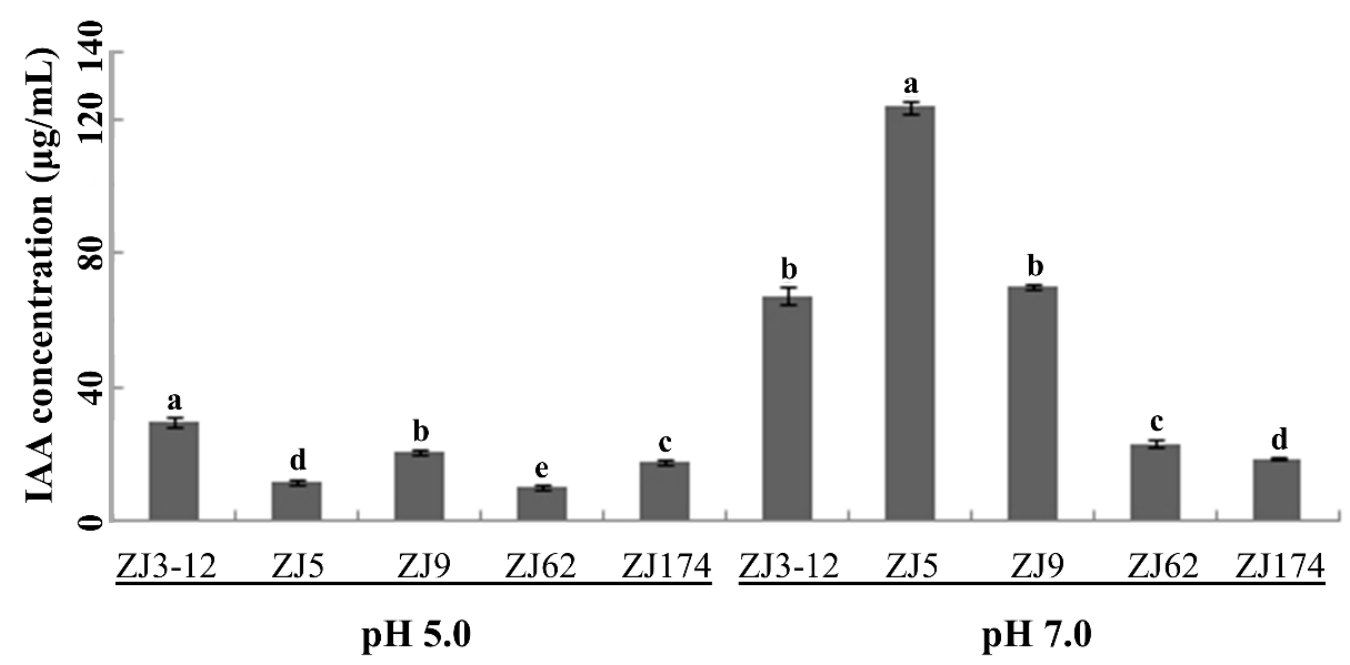

Figure 5. Effect of different $\mathrm{pH}$ on IAA production of five strains was determined by measuring the the amount of the produced IAA, which was expressed as $\mu \mathrm{g}$ IAA secreted per unit of optical density. The IAA concentration value was calculated based on a standard curve by measuring the optical density at a wave length of $530 \mathrm{~nm}$. A standard curve was drawn using serial dilutions of IAA. Values followed by different lowercase letters within the same $\mathrm{pH}$ indicate significant dif ference at $p<0.05$.

\subsection{Growth Promotion Effect of Eggplant Seedlings}

In order to examine the promotion effect of the five selected PGPB strains on plant growth, eggplant plants were sown in newly reclaimed soil under greenhouse conditions 
and plant growth parameters were evaluated after $30 \mathrm{~d}$ of inoculation with bacterial suspension. As shown in Figure 6, it can be seen that the five PGPB strains significantly promoted the growth of eggplant seedlings at different levels (Figure 6). Compared to the control, an obvious increase of leaf size was observed in the treatments inoculated with different bacterial strains. In particular, inoculation with strain ZJ9 resulted in the early flowering of eggplant plants (Figure 6C).

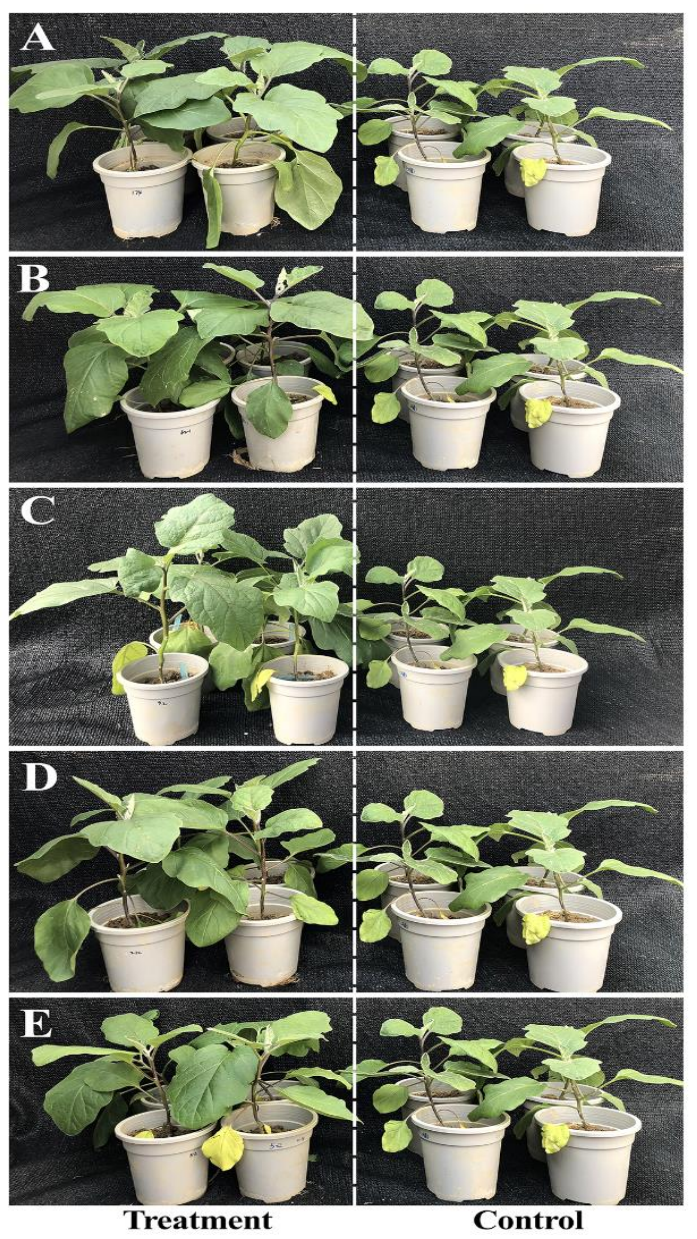

Figure 6. Effect of five bacterial strains on eggplant growth in new reclaimed soil $30 \mathrm{~d}$ after inoculation. After sowing the germinated seeds into the 32-cell seed growing trays containing the cocopeat substrate and growing for about 6 weeks, eggplant seedlings at the four-leaf stage were transplanted into pots containing unsterilized soil from the new reclamation land with $\mathrm{pH} 5.0$, while $10 \mathrm{~mL}$ of cell suspension (about $10^{8} \mathrm{cfu} / \mathrm{mL}$ ) of each test strain was poured into the soil around the plants. The plants inoculated with sterile water were used as the control. Each treatment had three replicates with 10 plants in each replicate. The photos of plants were taken by randomly placing 4 plants from each treatment. The uninoculated control plants from different treatments were the same. (A). Inoculation with strain ZJ174. (B). Inoculation with strain ZJ62. (C). Inoculation with strain ZJ9. (D). Inoculation with strain ZJ3-12. (E). Inoculation with strain ZJ5.

The measured data in this study showed that the five bacterial strains significantly affected plant growth and biomass in newly reclaimed soil compared to the controls $(p<0.05)$ (Table 3). Indeed, the inoculation of the five bacterial strains on eggplant plants caused a $12.52-34.50 \%$ increase in seedling height, a $26.22-49.33 \%$ increase in root length, a $16.05-76.37 \%$ increase in seedling fresh weigh, a $13.48-54.80 \%$ increase in seedling dry weight, a 33.77-154.89\% increase in root fresh weight, and an $8.32-53.42 \%$ increase in root dry weight compared to the control (Table 2). The ability of plant growth promotion depends on the bacterial strains. 
Table 3. Effect of five PGPB strains on growth promotion of eggplant plants at $30 \mathrm{~d}$ after bacterial inoculation.

\begin{tabular}{|c|c|c|c|c|c|c|c|c|c|c|c|c|}
\hline Strains & $\mathrm{SH}(\mathrm{cm})$ & GPE $\%$ & RL (cm) & GPE $\%$ & SFW (g) & GPE $\%$ & SDW (g) & GPE\% & RFW (g) & GPE\% & RDW (g) & GPE $\%$ \\
\hline ZJ3-12 & $16.67 \pm 0.46$ & $25.45 \mathrm{~b}$ & $32.80 \pm 0.88$ & $42.20 \mathrm{c}$ & $14.69 \pm 0.47$ & $50.17 \mathrm{c}$ & $1.91 \pm 0.11$ & $44.89 \mathrm{ab}$ & $3.44 \pm 0.22$ & $107.38 \mathrm{~b}$ & $0.51 \pm 0.06$ & $53.42 \mathrm{a}$ \\
\hline ZJ5 & $14.95 \pm 0.53$ & $12.52 \mathrm{c}$ & $30.08 \pm 0.98$ & $30.40 \mathrm{~d}$ & $11.36 \pm 0.47$ & $16.05 \mathrm{~d}$ & $1.50 \pm 0.07$ & $13.48 \mathrm{c}$ & $2.22 \pm 0.19$ & $33.77 \mathrm{c}$ & $0.36 \pm 0.05$ & $8.32 \mathrm{c}$ \\
\hline ZJ9 & $17.87 \pm 0.52$ & $34.50 \mathrm{a}$ & $29.12 \pm 0.71$ & $26.22 \mathrm{e}$ & $16.54 \pm 0.37$ & $69.06 \mathrm{~b}$ & $1.81 \pm 0.32$ & $37.39 \mathrm{~b}$ & $3.60 \pm 0.41$ & $117.01 \mathrm{~b}$ & $0.43 \pm 0.05$ & $28.95 \mathrm{~b}$ \\
\hline ZJ62 & $16.42 \pm 0.80$ & $23.57 \mathrm{~b}$ & $34.45 \pm 1.29$ & $49.33 \mathrm{a}$ & $16.18 \pm 0.87$ & $65.35 \mathrm{~b}$ & $1.90 \pm 0.11$ & $43.62 \mathrm{ab}$ & $3.63 \pm 0.37$ & $118.41 \mathrm{~b}$ & $0.46 \pm 0.07$ & $38.49 \mathrm{ab}$ \\
\hline ZJ174 & $16.38 \pm 0.95$ & $23.24 \mathrm{~b}$ & $33.72 \pm 0.86$ & $46.16 \mathrm{~b}$ & $17.26 \pm 0.71$ & 76.37 a & $2.04 \pm 0.21$ & $54.80 \mathrm{a}$ & $4.23 \pm 0.38$ & $154.89 \mathrm{a}$ & $0.47 \pm 0.07$ & $39.51 \mathrm{ab}$ \\
\hline Control & $13.29 \pm 0.45$ & - & $23.07 \pm 0.59$ & - & $9.79 \pm 0.504$ & - & $1.32 \pm 0.05$ & - & $1.66 \pm 0.15$ & - & $0.33 \pm 0.04$ & - \\
\hline
\end{tabular}

Dry weight measurement was performed by removing eggplant seedlings from each pot, rinsing with tap water, and then drying in an oven at $65{ }^{\circ} \mathrm{C}$ for $2 \mathrm{~d}$. The growth promotion efficacy (GPE) $\%=($ treatment - control) $/$ control $\times 100 \%$. Values followed by different lowercase letters within the same column indicate a significant difference at $p<0.05$. SL: Seedling height; RL: Root length; SFW: Seedling Fresh Weight; SDW: Seedling Dry Weight; RFW: Root Fresh Weight; RDW: Root Dry Weight.

At present, in order to increase farmers' income, Hangzhou is vigorously developing eggplant production by utilizing newly reclaimed soil from barren mountains. However, poor soil quality greatly restricts mountain eggplant production. Interestingly, the result of this study indicated that the five bacterial strains may have a great potential in promoting the growth of eggplants in immature soil from new reclaimed soil in Hangzhou. On the other hand, this result also confirmed our hypothesis that bacteria obtained from mountain soil have good growth-promoting effect. Consistent with our results, many other studies also found that phosphorus solubilizing bacteria isolated from acidic soil could promote plant growth [31,39].

Furthermore, it can also be inferred that the growth-promoting effect of the five bacterial strains may be related to their excellent ability in phosphate solubilization, nitrogen fixation, siderophore production and indole acetic acid production. In addition, this result also indicated that it is an effective method to screen PGPB bacteria from the newly reclaimed soil based on the ability of phosphate solubilization. Although these soil bacteria seem to have great prospects in eggplant production, it is still fully unclear about the influence of these PGPB bacteria on the properties and microbial communities of the mountain soil. In order to clarify the promoting mechanism of these PGPB bacteria, more experiments need to be carried out in the newly reclaimed soil in the mountain field.

\subsection{Bacterial Identification}

The identity of the five strains were identified by the BLAST searches of 16S rRNA gene sequences against the NCBI GenBank database, which showed that strain ZJ3-12 (GenBank access No. OK255669) and ZJ62 (GenBank access No. OK255670) were closely related to species of Pantoea with a similarity of $99.93 \%$ and $99.93 \%$ with P. ananatis strain IAE20 and $P$. dispersa strain PaKu20, respectively, whereas strains ZJ5 (GenBank access No. OK255666), ZJ9 (GenBank access No. OK255667), and ZJ174 (GenBank access No. OK255668) were closely related to species of Burkholderia cenocepacia strain CR318, Bacillus pyrrocinia strain DSM10685 and Burkholderia pyrrocinia strain DSM10685 with similarities of $99.93 \%, 100 \%$ and $99.93 \%$, respectively.

To determine the species of Pantoea, phylogenetic analysis was constructed in this study by using the four conversed genes, including gyrB, rpoB, atpD and infB. The phylogenetic tree showed that strains ZJ3-12 and ZJ62 were separated into different clades (Figure 7). Indeed, strain ZJ62 was clustered with P. dispersa strains LMG 152 and LMG $2603^{\mathrm{T}}$ as a distinct clade with a bootstrap of $100 \%$, suggesting this strain should be considered as $P$. dispersa. Furthermore, strain ZJ3-12 was clustered with $P$. ananatis strains LMG 2627, LMG 20106 and LMG $2665^{\mathrm{T}}$ as a clade with a bootstrap of $100 \%$, suggesting this strain should be considered as P. ananatis. 


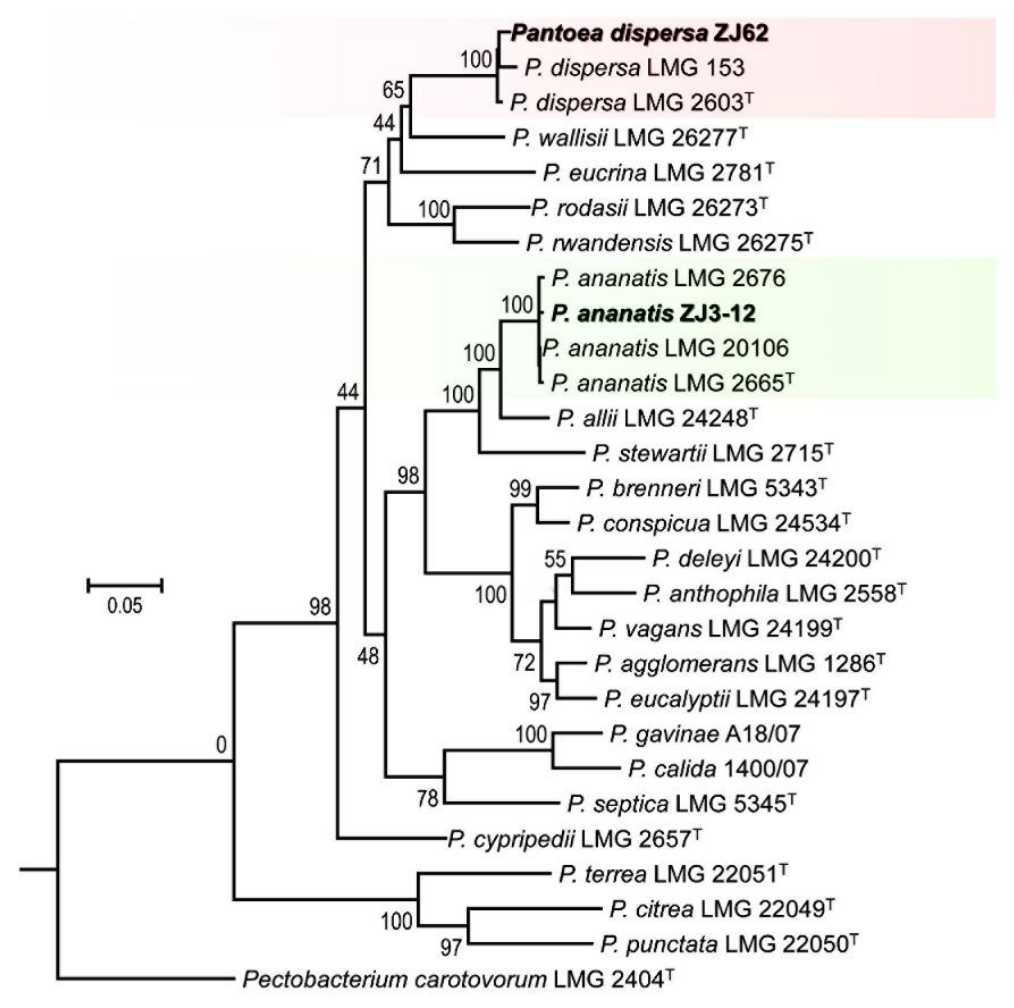

Figure 7. Maximum likelihood (ML) tree were constructed with RaxmlGUI v. 1.5 using the maximum likelihood method based on the concatenated sequences of $g y r B, r p o B$, atpD and infB of 28 Pantoea strains. The reference sequences of closely related species for Pantoea spp. were downloaded from GenBank database. Strains isolated from soil in this study are shown in bold. Bootstrap values after 1000 replicates are expressed as percentages. Pectobacterium carotovorum LMG $2404^{\mathrm{T}}$ was used as an outgroup. Type strain was indicated with $\mathrm{T}$.

In order to identify the species of the genus Burkholderia, phylogenetic analysis of strains ZJ5, ZJ9 and ZJ174 were carried out using the recA gene due to lack of a precise distinction among the genus using $16 \mathrm{~S}$ rRNA gene analysis [40,41]. The phylogenetic tree showed that the three bacterial strains isolated from soil belonged to two different Burkholderia species (Figure 8). Indeed, strains ZJ9 and ZJ174 were clustered together with the Burkholderia pyrrocinia belonging to genomovar IX [42], while strain ZJ5 was clustered with Burkholderia arboris belonging to cluster 3 [43]. Therefore, strains ZJ9 and ZJ174 should be identified as B. pyrrocinia, while strain ZJ5 should be identified as B. arboris (Figure 8).

The species identity of three Burkholderia strains was further determined using multilocus sequence analysis [40-46]. In agreement with the results obtained from the phylogenic analysis of $r e c A$ gene sequences, the phylogenetic tree constructed in this study using the concatenated sequences of seven housekeeping genes $(\operatorname{atp} D, g l t D, g y r B, \operatorname{rec} A, \operatorname{lep} A, p h a C$ and $\operatorname{tr} p B$ ) indicated that strains ZJ5 was clustered with the B. arboris strain Au1125 as a distinct clade with the $62 \%$ bootstrap value support and well separated from all other species. Strains ZJ9 and ZJ174 were clustered together as a clade with an $85 \%$ bootstrap value support, forming a clade with the B. pyrrocinia strains ATCC39277, R-13643 and AU24190 with $100 \%$ bootstrap value support (Figure 9). 


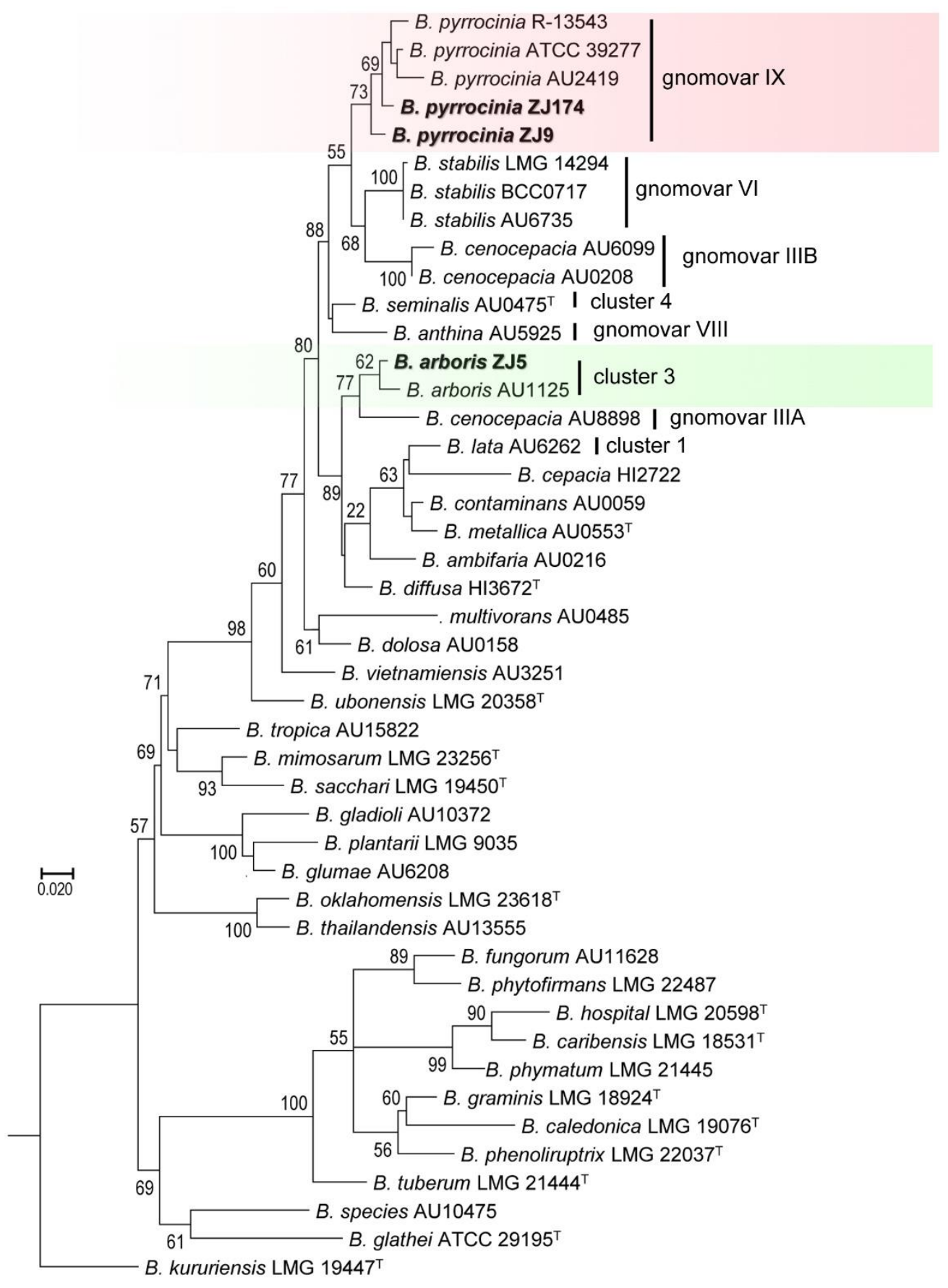

Figure 8. Phylogeny of Burkholderia species strains were constructed in this study with RaxmlGUI v. 1.5 using the maximum likelihood method based on the $\operatorname{rec} A$ gene sequences. The reference sequences of each species were downloaded from the Burkholderia cepacia complex multilocus sequence typing website (http:/ / pubmlst.org/bcc/; accessed on 26 August 2021). Percentage bootstrap values $>50 \%$ from 1000 samplings are indicated. B. kururiensis strain LMG $19447^{\mathrm{T}}$ was used as an outgroup. Strains isolated from soil in this study are shown in bold. Type strain was indicated with T. 


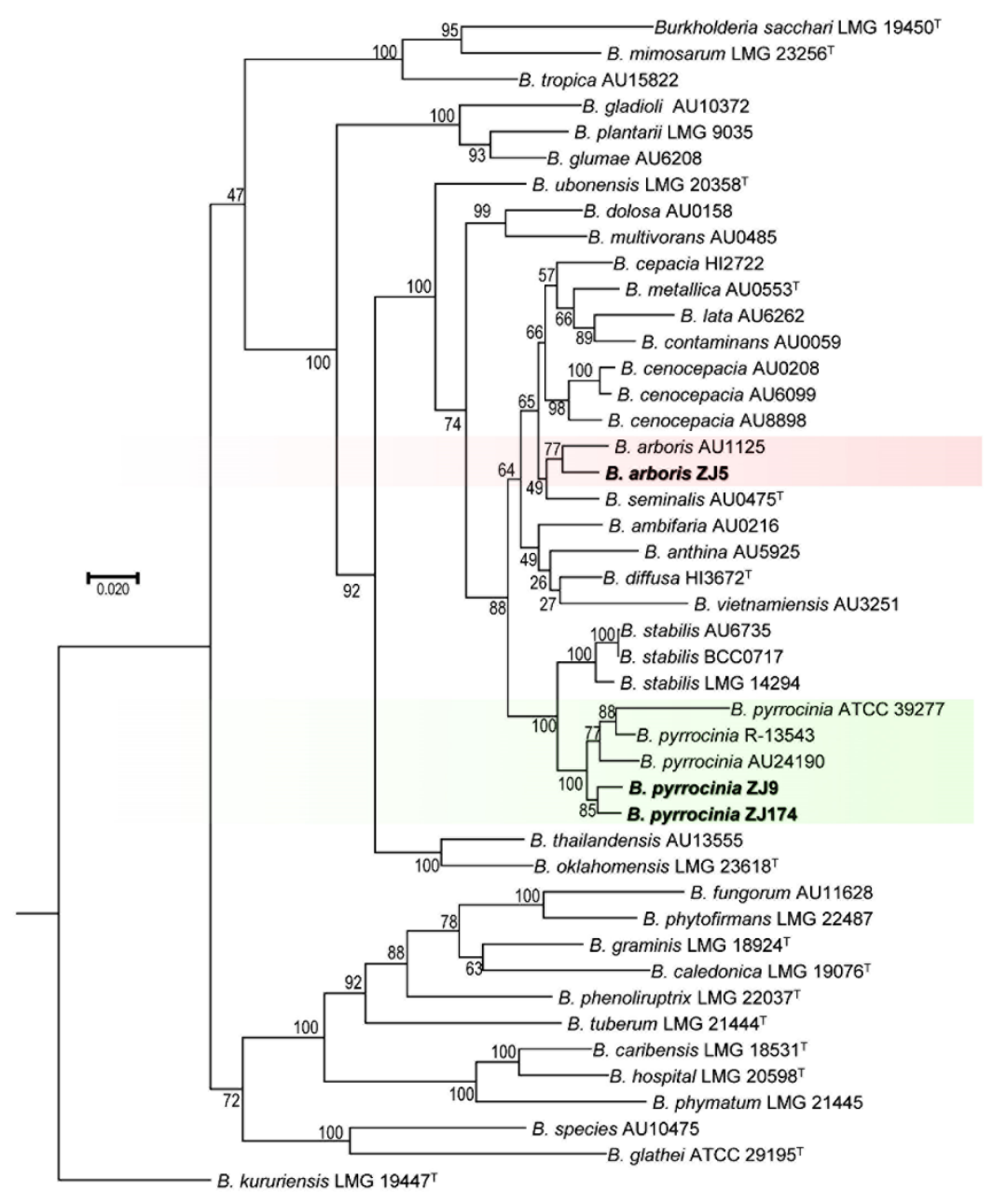

Figure 9. Maximum likelihood (ML) tree was generated with RaxmlGUI v. 1.5 from the combined $\operatorname{atpD}, g l t D, g y r B, \operatorname{rec} A, \operatorname{lep} A, p h a C$ and $\operatorname{trp} B$ genes sequences of 45 taxa of Burkholderia. The reference sequences of each species were downloaded from the Burkholderia cepacia complex multilocus sequence typing website (http://pubmlst.org/bcc/; accessed on 26 August 2021). The tree is rooted with B. kururiensis LMG $19447^{\mathrm{T}}$. Bootstrap scores (1000 replicates) are displayed at each node. Bacterial strains isolated from soil in this study are shown in bold. Type strain was indicated with T.

\section{Conclusions}

This study indicated that five out of 988 tested bacterial isolates showed excellent phosphate solubilization, nitrogen fixation, siderophore and IAA production ability at both pH 7.0 and $\mathrm{pH}$ 5.0, and plant growth promotion in immature soil from newly reclaimed land. The promoted effect in these parameters depends on both bacterial strains and pH. Furthermore, strains ZJ62 and ZJ3-12 were identified as P. dispersa and P. ananatis, respectively, while strains ZJ5, ZJ9 and ZJ174 was identified as B. arboris, B. pyrrocinia and $B$. pyrrocinia, respectively, based on colony morphology observation and phylogenetic analysis of $16 \mathrm{~S}$ rDNA and the housekeeping genes sequences. Overall, this study showed that the five selected bacterial strains have great potential in promoting plant growth in immature soil obtained from newly reclaimed land.

Supplementary Materials: The following are available online at https:/ /www.mdpi.com/article/10 .3390/agriculture11121258/s1, Table S1: The reference sequences of Pantoea closely related species were downloaded from GenBank database. Table S2: The reference sequences of each Burkholderia species were downloaded from the Bcc multilocus sequence typing website. 
Author Contributions: Conceptualization, X.L., J.Y., D.L., Y.J., Y.Z., H.W., J.Z., T.A., B.L.; methodology, X.L., D.L., T.A.; software, X.L., D.L.; validation, X.L., D.L.; formal analysis, X.L., D.L., Y.Z., H.W., T.A.; investigation, X.L., D.L.; resources, X.L., D.L., J.Y., J.Z.; data curation, X.L. and J.Y.; writingoriginal draft preparation, X.L., D.L., J.Y., Y.Z.; H.W., J.Z., T.A., B.L.; writing-review and editing, J.Y., J.Z., B.L.; visualization, J.Y., J.Z., B.L.; supervision, J.Y., J.Z. and B.L.; project administration, J.Y. and J.Z.; funding acquisition, J.Y. and J.Z. All authors have read and agreed to the published version of the manuscript.

Funding: This research was funded by the key research and development program of Zhejiang province (2019C02035), Science and technology innovation and promotion demonstration project of Hangzhou Academy of Agricultural Sciences (2020HNCT-12, 2019HNCT-03).

Institutional Review Board Statement: Not applicable.

Informed Consent Statement: Not applicable.

Data Availability Statement: The data presented in this study are available within the article.

Conflicts of Interest: The authors declare no conflict of interest.

\section{References}

1. Ghose, B. Food security and food self-sufficiency in China: From past to 2050. Food Energy Secur. 2014, 3, 86-95. [CrossRef]

2. Li, X.; Su, Y.; Ahmed, T.; Ren, H.; Javed, M.R.; Yao, Y.; An, Q.; Yan, J.; Li, B. Effects of Different Organic Fertilizers on Improving Soil from Newly Reclaimed Land to Crop Soil. Agriculture 2021, 11, 560. [CrossRef]

3. Larney, F.J.; Angers, D.A. The role of organic amendments in soil reclamation: A review. Can. J. Soil Sci. 2012, 92, 19-38. [CrossRef]

4. Gómez-Sagasti, M.T.; Hernández, A.; Artetxe, U.; Garbisu, C.; Becerril, J.M. How valuable are organic amendments as tools for the phytomanagement of degraded soils? The knowns, known unknowns, and unknowns. Front. Sustain. 2018, 2, 68. [CrossRef]

5. Gupta, A.; Gupta, R.; Singh, R.L. Microbes and environment. In Principles and Applications of Environmental Biotechnology for a Sustainable Future; Springer: Berlin/Heidelberg, Germany, 2017; pp. 43-84.

6. Dutta, S.; Podile, A.R. Plant growth promoting rhizobacteria (PGPR): The bugs to debug the root zone. Crit. Rev. Microbiol. 2010, 36, 232-244. [CrossRef] [PubMed]

7. Li, X.; Li, D.; Yan, J.; Zhang, Y.; Wang, H.; Zhang, J.; Ahmed, T.; Li, B. Effects of Plant-Growth-Promoting Fungi on Eggplant (Solanum melongena L.) in Newly Reclaimed Land. Agriculture 2021, 11, 1036. [CrossRef]

8. Ali, L.; Manzoor, N.; Li, X.; Naveed, M.; Nadeem, S.; Waqas, M.; Khalid, M.; Abbas, A.; Ahmed, T.; Li, B.; et al. Impact of Corn Cob-Derived Biochar in Altering Soil Quality, Biochemical Status and Improving Maize Growth under Drought Stress. Agronomy 2021, 11, 2300. [CrossRef]

9. Souza, R.d.; Ambrosini, A.; Passaglia, L.M. Plant growth-promoting bacteria as inoculants in agricultural soils. Genet. Mol. Biol. 2015, 38, 401-419. [CrossRef]

10. Basu, A.; Prasad, P.; Das, S.N.; Kalam, S.; Sayyed, R.; Reddy, M.; El Enshasy, H. Plant growth promoting rhizobacteria (PGPR) as green bioinoculants: Recent developments, constraints, and prospects. Sustainability 2021, 13, 1140. [CrossRef]

11. Egamberdieva, D.; Adesemoye, A.O. Improvement of crop protection and yield in hostile agroecological conditions with PGPRbased biofertilizer formulations. In Bioformulations: For Sustainable Agriculture; Springer: Berlin/Heidelberg, Germany, 2016; pp. 199-211.

12. Kalam, S.; Basu, A.; Podile, A.R. Functional and molecular characterization of plant growth promoting Bacillus isolates from tomato rhizosphere. Heliyon 2020, 6, e04734. [CrossRef] [PubMed]

13. Gouda, S.; Kerry, R.G.; Das, G.; Paramithiotis, S.; Shin, H.-S.; Patra, J.K. Revitalization of plant growth promoting rhizobacteria for sustainable development in agriculture. Microbiol. Res. 2018, 206, 131-140. [CrossRef]

14. Mehta, S.; Nautiyal, C.S. An efficient method for qualitative screening of phosphate-solubilizing bacteria. Curr. Microbiol. 2001, 43, 51-56. [CrossRef]

15. Kuan, K.B.; Othman, R.; Rahim, K.A.; Shamsuddin, Z.H. Plant Growth-promoting rhizobacteria inoculation to enhance vegetative growth, nitrogen fixation and nitrogen remobilisation of maize under greenhouse conditions. PLoS ONE 2016, 11, e0152478. [CrossRef]

16. Chauhan, A.; Saini, R.; Sharma, J.C. Plant growth promoting rhizobacteria and their biological properties for soil enrichment and growth promotion. J. Plant Nutr. 2021, 45, 273-299. [CrossRef]

17. Olenska, E.; Malek, W.; Wojcik, I.; Swiecicka, I.; Thijs, S.; Vangronsveld, J. Beneficial features of plant growth-promoting rhizobacteria for improving plant growth and health in challenging conditions: A methodical review. Sci. Total Environ. 2020, 743, 140682. [CrossRef]

18. Abdallah, Y.; Yang, M.; Zhang, M.; Masum, M.M.; Ogunyemi, S.O.; Hossain, A.; An, Q.; Yan, C.; Li, B. Plant growth promotion and suppression of bacterial leaf blight in rice by Paenibacillus polymyxa Sx3. Lett. Appl. Microbiol. 2019, 68, 423-429. [CrossRef]

19. Kumar, V.; Narula, N. Solubilization of inorganic phosphates and growth emergence of wheat as affected by Azotobacter chroococcum. Biol. Fertil. Soil. 1999, 27, 301-305. [CrossRef] 
20. Murugappan, R.; Aravinth, A.; Karthikeyan, M. Chemical and structural characterization of hydroxamate siderophore produced by marine Vibrio harveyi. J. Ind. Microbiol. Biotechnol. 2011, 38, 265-273. [CrossRef]

21. Tang, A.; Haruna, A.O.; Majid, N.M.A.; Jalloh, M.B. Potential PGPR properties of cellulolytic, nitrogen-fixing, phosphatesolubilizing bacteria in rehabilitated tropical forest soil. Microorganisms 2020, 8, 442. [CrossRef] [PubMed]

22. Khamna, S.; Yokota, A.; Lumyong, S. Actinomycetes isolated from medicinal plant rhizosphere soils: Diversity and screening of antifungal compounds, indole-3-acetic acid and siderophore production. World J. Microbiol. Biotechnol. 2009, 25, 649-655. [CrossRef]

23. Tomah, A.A.; Abd Alamer, I.S.; Li, B.; Zhang, J.-Z. A new species of Trichoderma and gliotoxin role: A new observation in enhancing biocontrol potential of T. virens against Phytophthora capsici on chili pepper. Biol. Control 2020, 145, 104261. [CrossRef]

24. Alamer, A.; Sabah, I.; Tomah, A.A.; Li, B.; Zhang, J.-Z. Isolation, identification and characterization of rhizobacteria strains for biological control of bacterial wilt (Ralstonia solanacearum) of eggplant in China. Agriculture 2020, 10, 37. [CrossRef]

25. Hall, T.; Biosciences, I.; Carlsbad, C. BioEdit: An important software for molecular biology. GERF Bull. Biosci. $2011,2,60-61$.

26. Silvestro, D.; Michalak, I. raxmlGUI: A graphical front-end for RAxML. Org. Divers. Evol. 2012, 12, 335-337. [CrossRef]

27. Wissuwa, M. How do plants achieve tolerance to phosphorus deficiency? Small causes with big effects. Plant Physiol. 2003, 133, 1947-1958. [CrossRef]

28. Azaroual, S.E.; Hazzoumi, Z.; Mernissi, N.E.; Aasfar, A.; Kadmiri, I.M.; Bouizgarne, B. Role of Inorganic Phosphate Solubilizing Bacilli Isolated from Moroccan Phosphate Rock Mine and RhizosphereSoils in Wheat (Triticum aestivum L) Phosphorus Uptake. Curr. Microbiol. 2020, 77, 2391-2404. [CrossRef]

29. Hii, Y.S.; San, C.Y.; Lau, S.W.; Danquah, M.K. Isolation and characterisation of phosphate solubilizing microorganisms from peat. Biocatal. Agric. Biotechnol. 2020, 26, 101643. [CrossRef]

30. Pastore, G.; Kaiser, K.; Kernchen, S.; Spohn, M. Microbial release of apatite- and goethite-bound phosphate in acidic forest soils. Geoderma 2020, 370, 114360. [CrossRef]

31. Mpanga, I.K.; Ludewig, U.; Dapaah, H.K.; Neumann, G. Acquisition of rock phosphate by combined application of ammonium fertilizers and Bacillus amyloliquefaciens FZB42 in maize as affected by soil pH. J. Appl. Microbiol. 2020, 129, 947-957. [CrossRef]

32. Sheng, M.M.; Jia, H.K.; Zhang, G.Y.; Zeng, L.N.; Zhang, T.T.; Long, Y.H.; Lan, J.; Hu, Z.Q.; Zeng, Z.; Wang, B.; et al. Siderophore Production by Rhizosphere Biological Control Bacteria Brevibacillus brevis GZDF3 of Pinellia ternata and Its Antifungal Effects on Candida albicans. J. Microbiol. Biotechnol. 2020, 30, 689-699. [CrossRef]

33. Parveen, S.R.; Latha, D. Characterization of Siderophore Producing Pseudomonas sp. for its Plant Growth Promoting Properties. Biosci. Biotechnol. Res. Commun. 2019, 12, 1031-1037. [CrossRef]

34. Rengel, Z.; Marschner, P. Nutrient availability and management in the rhizosphere: Exploiting genotypic differences. New Phytol. 2005, 168, 305-312. [CrossRef]

35. Wang, X.; Zhang, M.; Loh, B.; Leptihn, S.; Ahmed, T.; Li, B. A novel NRPS cluster, acquired by horizontal gene transfer from algae, regulates siderophore iron metabolism in Burkholderia seminalis R456. Int. J. Biol. Macromol. 2021, 182, 838-848. [CrossRef] [PubMed]

36. Ali, M.; Lou, Y.; Hafeez, R.; Li, X.; Hossain, A.; Xie, T.; Lin, L.; Li, B.; Yin, Y.; Yan, J. Functional analysis and genome mining reveal high potential of biocontrol and plant growth promotion in nodule-inhabiting bacteria within Paenibacillus polymyxa Complex. Front. Microbiol. 2021, 11, 3627. [CrossRef]

37. Gajalakshmi, K.; Dhivya, K. Characterization of Potential Plant Growth Promoting Rhizobacteria Isolated from Rhizospheric soil of Banana (Musa paradisiaca L.). Res. J. Biotechnol. 2021, 16, 140-145.

38. Altinkaynak, H.; Ozkoc, I. Isolation and molecular characterization of plant growth promoting bacteria from the rhizosphere of orchids in Turkey. Rhizosphere 2020, 16, 100280. [CrossRef]

39. Henri, F.; Laurette, N.N.; Annette, D.; John, Q.; Wolfgang, M.; Francois-Xavier, E.; Dieudonne, N. Solubilization of inorganic phosphates and plant growth promotion by strains of Pseudomonas fluorescens isolated from acidic soils of Cameroon. Afr. J. Microbiol. Res. 2008, 2, 171-178.

40. Zhang, M.C.; Wang, X.X.; Ahmed, T.; Liu, M.J.; Wu, Z.F.; Luo, J.Y.; Tian, Y.; Jiang, H.B.; Wang, Y.L.; Sun, G.C.; et al. Identification of genes involved in antifungal activity of Burkholderia seminalis against Rhizoctonia solani using Tn 5 transposon mutation method. Pathogens 2020, 9, 797. [CrossRef] [PubMed]

41. Lou, M.M.; Zhu, B.; Ibrahim, M.; Li, B.; Xie, G.L.; Li, H.Y. Antibacterial activity and mechanism of action of chitosan solution against apricot fruit rot pathogen Burkholderia seminalis. Carbohydr. Res. 2011, 346, 1294-1301. [CrossRef] [PubMed]

42. Baldwin, A.; Mahenthiralingam, E.; Thickett, K.M.; Honeybourne, D.; Maiden, M.C.; Govan, J.R.; Speert, D.P.; LiPuma, J.J.; Vandamme, P.; Dowson, C.G. Multilocus sequence typing scheme that provides both species and strain differentiation for the Burkholderia cepacia complex. J. Clin. Microbiol. 2005, 43, 4665-4673. [CrossRef]

43. Vanlaere, E.; LiPuma, J.J.; Baldwin, A.; Henry, D.; De Brandt, E.; Mahenthiralingam, E.; Speert, D.; Dowson, C.; Vandamme, P. Burkholderia latens sp. nov., Burkholderia diffusa sp. nov., Burkholderia arboris sp. nov., Burkholderia seminalis sp. nov. and Burkholderia metallica sp. nov., novel species within the Burkholderia cepacia complex. Int. J. Syst. Evol. Microbiol. 2008, 58, 1580-1590. [CrossRef] [PubMed]

44. Zhu, B.; Ibrahim, M.; Cui, Z.Q.; Xie, G.L.; Jin, G.L.; Kube, M.; Li, B.; Zhou, X.P. Multi-omics analysis of niche specificity provides new insights into ecological adaptation in bacteria. ISME J. 2016, 10, 2072-2075. [CrossRef] 
45. Li, B.; Liu, B.P.; Yu, R.R.; Lou, M.M.; Wang, Y.L.; Xie, G.L.; Li, H.Y.; Sun, G.C. Phenotypic and molecular characterization of rhizobacterium Burkholderia sp. strain R456 antagonistic to Rhizoctonia solani, sheath blight of rice. World J. Microbiol. Biotechnol. 2011, 27, 2305-2313. [CrossRef]

46. Li, B.; Fang, Y.; Zhang, G.Q.; Yu, R.R.; Lou, M.M.; Xie, G.L.; Wang, Y.L.; Sun, G.C. Molecular characterization of Burkholderia cepacia complex isolates causing bacterial fruit rot of apricot. Plant Pathol. J. 2010, 26, 223-230. [CrossRef] 